\title{
Changes in phosphate content and phosphatase activities in rice seedlings exposed to arsenite
}

\author{
Shruti Mishra and R.S. Dubey*
}

Department of Biochemistry, Faculty of Science, Banaras Hindu University, Varanasi 221005, India. *Corresponding author:rsdbhu@rediffmail.com

Received: 16 August 2007; Returned for revision: 07 December 2007; Accepted: 13 February 2008

The effect of arsenite $\left(\mathrm{As}_{2} \mathrm{O}_{3}\right)$ in situ on the level of the phosphate pool and activities of phosphohydrolytic enzymes was examined in rice (Oryza sativa L.) seedlings grown for 5-20 d in sand cultures. The effects were manifested via a decline in phosphate content and inhibition of the activities of key phosphatases. Application of $50 \mu \mathrm{M} \mathrm{As}_{2} \mathrm{O}_{3}$ in situ resulted in 34 to $77 \%$ inhibition of acid phosphatase activity in roots and about 38 to $50 \%$ inhibition of activity in shoots of 15-20-d-old seedlings. Similarly, alkaline phosphatase activity was inhibited in shoots under in situ As (III) toxicity. Varietal as well as organ specific differences were observed in the response of inorganic pyrophosphatase activity to in situ As (III) treatment. A moderately toxic in situ $\mathrm{As}_{2} \mathrm{O}_{3}$ level of $25 \mu \mathrm{M}$ as well as a highly toxic level of $50 \mu \mathrm{M}$ inhibited mitochondrial-ATPase activity whereas $25 \mu \mathrm{M}$ As (III) stimulated the chloroplastic isoform of ATPase but at a higher level $(50 \mu \mathrm{M})$ As (III) was inhibitory. The results suggest that exposure of rice plants to arsenite leads to lowering of the phosphate pool and alteration in the activities of key phosphohydrolytic enzymes which might contribute to metabolic perturbations and decreased growth of rice plants in an As (III) polluted environment.

Key words: arsenite, chloroplast, mitochondria, Oryza sativa, phosphate, phosphatases

Variações no conteúdo de fosfato e atividades de fosfatases em plântulas de arroz expostas a arsenito: Examinou-se, in situ, o efeito do arsenito $\left(\mathrm{As}_{2} \mathrm{O}_{3}\right)$ sobre o estoque de fosfato e atividades de enzimas fosfoidrolíticas em plântulas de arroz (Oryza sativa L.) cultivadas por 5-20 d em areia. Os efeitos foram manifestados via decréscimos no conteúdo de fosfato e inibição das atividades de fosfatases-chave. A aplicação de $50 \mu \mathrm{M}$ de $\mathrm{As}_{2} \mathrm{O}_{3}$ in situ resultou em inibição de 34 a $77 \%$ na atividade de fosfatases nas raízes, e uma inibição na atividade de cerca de 38 a 50\% na parte aérea de plântulas com 15 a 20 d. Similarmente, a atividade da fosfatase alcalina foi inibida na parte aérea sob toxidez de As(III). Observaram-se diferenças específicas entre variedades e órgãos na resposta da atividade da fosfatase inorgânica ao tratamento in situ com As(III). Toxidez moderada de $\mathrm{As}_{2} \mathrm{O}_{3}(25 \mu \mathrm{M})$ assim como um nível altamente tóxico de $50 \mu \mathrm{M}$ inibiram a atividade de ATPase mitocondrial enquanto $25 \mu \mathrm{M}$ As(III) estimulou a isoforma cloroplastídica da ATPase, porém a dose mais elevada $(50 \mu \mathrm{M})$ foi inibitória. Os resultados sugerem que a exposição de plantas de arroz ao arsenito leva a um decréscimo do estoque de fosfato e alteração nas atividades de enzimas fosfoidrolíticas, o que poderia contribuir para causar distúrbios metabólicos e redução do crescimento de plantas de arroz em ambientes contaminados com As(III).

Palavras-chave: arsenito, cloroplasto, fosfato, fosfatase, mitocôndria, Oryza sativa

\section{INTRODUCTION}

Phosphorus is an essential nutrient for plants and an important component in cell metabolism. It has a vital functional role in energy transfer, and acts as modulator of enzyme activity and gene transcription; hence its assimilation, storage and metabolism are of major importance to plant growth and development (Duff et al., 1994). Hydrolytic breakdown of phosphate esters is brought about by phosphatases, which is a critical process in energy metabolism, metabolic regulation and a 
wide range of signal transduction pathways in plants (Vicent et al., 1992, Duff et al., 1994). Phosphatases catalyze reactions that result in the liberation of inorganic phosphorus (Pi) from various substrates in a thermodynamically favourable process, which occurs in both acidic and alkaline medium (Barret-Lennard et al., 1982). Inorganic phosphorus is a nutrient that often limits plant growth in a natural environment. Acid phosphatases (EC 3.1.3.2, orthophosphoric-monoester phosphohydrolases) having broad and overlapping substrate specificities are ubiquitous and abundant enzymes in plants and catalyze non-specific hydrolysis of $\mathrm{Pi}$ from phosphate monoesters in $\mathrm{pH}$ ranges from 4 to 6 and play a major role in the supply and metabolism of phosphate in plants (Duff et al., 1994, Tabaldi et al., 2007). Similarly alkaline phosphatases (EC 3.1.3.1) have a potential role in utilization of phosphomonoesters as the source of Pi required for maintenance of cellular metabolism (Orhanović and Pavela-Vrancic $v$, 2000). Inorganic pyrophosphatase (EC 3.6.1.1) catalyzes pyrophosphate hydrolysis and synthesis and enriches the phosphate pool in plants by hydrolyzing inorganic pyrophosphate to two molecules of Pi (Cooperman, 1982; Beknazarov and Valikhanov, 2007). Inorganic pyrophosphate is a by-product of a number of biosynthetic reactions and is essential for the regulation of many biochemical reactions in plant cells (Beknazarov and Valikhanov, 2007). Adenosine triphosphatases (ATPases) have wide occurrence in plant tissues and participate in active transport of molecules and ions across membranes and in cell biosynthetic processes (Martinez-Ballesta et al., 2003).

Stressful conditions of the environment adversely affect $P$ nutrition and its metabolism in plants. Activities of the phosphorolytic enzymes acid phosphatase, alkaline phosphatase, and ATPase show significant alteration in plants exposed to abiotic stressful conditions of the environment such as soil salinity (Ehsanpour and Amini, 2003), osmotic stress (Szabo Nagy et al., 1992), excess of heavy metals (Shah and Dubey, 1998), etc.

Elevated levels of metals in the soil environment cause toxicity in growing plants and reduce crop productivity. Arsenic is a highly toxic metal to all forms of life. Vast areas of Southeast Asia are under threat from arsenic contaminated ground water (World Bank and
WSP, 2005). Irrigation with arsenic laden water gradually adds this metal to the soil surface layers (Abedin et al., 2002). Deposition of arsenic in the soil environment leads to toxicity in growing plants. Background levels of arsenic in contaminated soils generally reach 4 to $8 \mathrm{mg}$ As $\mathrm{kg}^{-1}$ but may reach as high as $83 \mathrm{mg} \mathrm{As} \mathrm{kg}^{-1}$ (Abedin et al., 2002), whereas ground water used for irrigation may contain up to 80-180 $\mu \mathrm{g} \mathrm{As} \mathrm{L}^{-1}$ (Green et al., 2006). In recent years arsenic has emerged as a potent metal poison and an alarming increase in its content in agricultural soils and different parts of crop plants has set a challenge to crop production in many parts of the world (Abedin et al., 2002; Meharg and Hartley-Whitaker, 2002; Tripathi et al., 2007).

Rice is a staple food crop for a majority of the world population and is cultivated in many regions of the world where ground water is severely contaminated with arsenic (Abedin et al., 2002; Meharg, 2004; Williams et al., 2007). The redox active forms of arsenic that cause intoxication to plants are arsenite (As III) and arsenate (As V). Both these soluble forms can be found in soil and water, but under growth conditions of paddy fields arsenite predominates, due to the partial anaerobic conditions. Consequently, the +3 oxidation state is regarded as responsible for arsenic toxicity in this environment (Onken and Hossner, 1995; Meharg, 2004). Although it has been shown that excess arsenic in the soil affects a number of physiological and biochemical reactions in plants (Jha and Dubey, 2004; Mishra and Dubey, 2006), the precise mechanisms underlying arsenic phytotoxicity are poorly understood (Requejo and Tena, 2006).

Earlier studies conducted in our laboratory using two rice cultivars indicated that, after the uptake, arsenite is translocated to different parts of the plant, although more was found in roots than in shoots (Jha and Dubey, 2004). In order to identify arsenic phytotoxicity targets related to $\mathrm{P}$ metabolism in rice plants, the present study was undertaken to examine the effects of increasing levels of $\mathrm{As}_{2} \mathrm{O}_{3}$ in the growth medium on the size of the phosphate pool and the activities of the phosphohydrolase enzymes, namely acid phosphatase, alkaline phosphatase, inorganic pyrophosphatase and chloroplastic as well as mitochondrial isoforms of adenosine triphosphatases, in growing rice seedlings. 


\section{MATERIAL AND METHODS}

Plant material and treatment conditions: Seeds of two rice (Oryza sativa L.) cultivars sensitive to arsenic, namely Malviya-36 and Pant-12 (Jha and Dubey, 2004) were surface sterilized with $1 \%$ sodium hypochlorite solution and then imbibed in water for $24 \mathrm{~h}$. Seedlings were raised in sand cultures in plastic pots saturated with either Hoagland's nutrient solution (Hoagland and Arnon, 1938) which served as control or nutrient solutions supplemented with $\mathrm{As}_{2} \mathrm{O}_{3}$ to achieve arsenic concentrations of $25 \mu \mathrm{M}$ and $50 \mu \mathrm{M}$, which served as treatment solutions. Seedlings were raised in the greenhouse for $20 \mathrm{~d}$ at $28 \pm 1^{\circ} \mathrm{C}$, at $80 \%$ relative humidity and with a $12 \mathrm{~h}$ light/dark cycle (40-50 $\mu \mathrm{mol} \mathrm{m} \mathrm{m}^{-2} \mathrm{~s}^{-1}$ irradiance). On alternate days, pots received the respective control and $\mathrm{As}_{2} \mathrm{O}_{3}$ solutions to saturate the sand. The pots were kept at field saturation capacity by irrigation. Seedlings were harvested for analysis at 5-d intervals up to $20 \mathrm{~d}$ and all experiments were performed using roots and shoots composed of triplicate samples from independent plants.

Extraction and estimation of phosphate: Total phosphate was extracted from roots and shoots of seedlings at different days of growth by acid digestion of about $100 \mathrm{mg}$ oven dried $\left(70^{\circ} \mathrm{C}\right.$ for $\left.3 \mathrm{~d}\right)$ samples. The final volume was made up to $10 \mathrm{~mL}$ with water. Phosphate was estimated according to the method of Fiske and Subbarow (1925). Absorbance was measured at $660 \mathrm{~nm}$ in an ELICO SL-177 spectrophotometer (Hyderabad, India), using $\mathrm{KH}_{2} \mathrm{PO}_{4}$ as a phosphate standard.

Assay of acid phosphatase, alkaline phosphatase and inorganic pyrophosphatase activity: About $200 \mathrm{mg}$ root and shoot samples from freshly harvested seedlings were used for enzyme extractions and assays. The activities of all the three enzymes were assayed according to the method of Tominaga and Takeshi, (1974). For acid phosphatase assay, samples were extracted in $5 \mathrm{~mL}$ of 100 $\mathrm{mM}$ sodium acetate buffer ( $\mathrm{pH} 4.5$ ) using a chilled mortar and pestle. Homogenates were centrifuged at 22,000 $\mathrm{x} g$ at $4^{\circ} \mathrm{C}$ for $10 \mathrm{~min}$. and the supernatants placed in cellophane membrane tubing and dialyzed against extraction buffer in the cold for $8 \mathrm{~h}$ with 3-4 changes of buffer. The assay mixture contained $5 \mathrm{mM}$ disodium $p$-nitrophenyl phosphate as substrate, $50 \mathrm{mM}$ acetate buffer $(\mathrm{pH} 4.5)$ and $0.2 \mathrm{~mL}$ dialyzed enzyme extract in a total volume of 1 $\mathrm{mL}$. After incubation for $30 \mathrm{~min}$ at $30^{\circ} \mathrm{C}$, the reaction was terminated by addition of $4.0 \mathrm{~mL}$ of $100 \mathrm{mM} \mathrm{NaOH}$. The amount of $p$-nitrophenol liberated was measured by recording the absorbance at $400 \mathrm{~nm}$. One nkat of enzyme activity is defined as one nmol $p$-nitrophenol liberated $\mathrm{s}^{-1}$ and specific activity as nkat $\mathrm{mg}^{-1}$ protein.

The procedure employed for the assay of alkaline phosphatase was similar to acid phosphatase except that for enzyme extraction and incubation $100 \mathrm{mM}$ sodium bicarbonate buffer (pH 10.0) was used.

For the assay of inorganic pyrophosphatase roots and shoots were homogenized in $5 \mathrm{~mL}$ of $0.1 \mathrm{M}$ glycine$\mathrm{NaOH}$ buffer ( $\mathrm{pH}$ 8.8). After centrifugation the supernatant was dialyzed. The assay mixture contained 4 $\mu \mathrm{mol} \mathrm{Na} \mathrm{P}_{2} \mathrm{O}_{7}, 100 \mu \mathrm{mol}$ glycine-NaOH buffer ( $\mathrm{pH} 8.8$ ), 10 $\mu \mathrm{mol} \mathrm{MgCl}_{2}$ and enzyme in a total volume of $2 \mathrm{~mL}$. After incubation for $20 \mathrm{~min}$ at $30^{\circ} \mathrm{C}$ the reaction was stopped by adding $0.5 \mathrm{~mL}$ of $30 \%$ trichloroacetic acid. Any precipitate formed was removed by centrifugation and the supernatant used for the determination of Pi according to the method of Fiske and Subbarow, (1925). Enzyme specific activity was expressed as nkat $\mathrm{mg}^{-1}$ protein.

Isolation of chloroplasts and mitochondria: About $1.0 \mathrm{~g}$ fresh roots and leaves of rice seedlings at different times of growth was used to isolate chloroplasts and mitochondria, according to Atal et al. (1991) and Wedding et al. (1976), respectively. All operations were carried out at $4{ }^{\circ} \mathrm{C}$. Integrity of chloroplasts was checked using the ferricyanide assay and of mitochondria using the cytochrome-c oxidase enzyme method according to Saloman et al. (1987). Freeze-thaw extracts of chloroplasts and mitochondria were prepared by suspending the chloroplastic/mitochondrial pellet in $2 \mathrm{~mL} 100 \mathrm{mM}$ Tris$\mathrm{HCl}$ buffer ( $\mathrm{pH} 7.5$ ), freezing at $20^{\circ} \mathrm{C}$ for $24 \mathrm{~h}$ followed by thawing at room temperature. After repeating this procedure thrice, the thawed suspension was centrifuged at 22,000 x g for $30 \mathrm{~min}$. The clear supernatant served as enzyme extract in which ATPase activity was assayed.

Assay of ATPase activity: Activity of ATPase was assayed in enzyme preparations from mitochondria and chloroplasts according to the method of Tominaga (1978) with some modifications. The assay mixture contained 80 
$\mu$ mol Tris-HCl buffer (pH 7.5), $10 \mu \mathrm{mol} \mathrm{Na}_{2} \mathrm{ATP}, 20 \mu \mathrm{mol}$ $\mathrm{MgCl}_{2}, 1 \mathrm{mM}$ EDTA and $0.2 \mathrm{~mL}$ enzyme in a total volume of $2 \mathrm{~mL}$. After incubation for $20 \mathrm{~min}$ at $30^{\circ} \mathrm{C}$, the reaction was terminated by the addition of $0.5 \mathrm{~mL}$ ice-cold $30 \%$ TCA. After centrifugation $\mathrm{Pi}$ was estimated in the supernatant by the method of Fiske and Subbarow (1925). Specific activity of the enzyme was expressed as $\mu \mathrm{mol} \mathrm{Pi}$ liberated $\mathrm{min}^{-1} \mathrm{mg}^{-1}$ protein.

Protein content in all enzyme preparations was determined according to the method of Bradford (1976) using BSA as standard.

Statistical analysis: All data were analyzed statistically using SPSS statistical software (SPSS 10 for Windows) by one-way ANOVA followed by the Tukey test taking $P<$ 0.05 as significant.

\section{RESULTS}

Effect of arsenite on phosphate level in growing rice seedlings: Studies performed to examine the level of phosphate in roots and shoots of rice seedlings growing under increasing concentration of arsenite in the medium indicated a decline in phosphate content with increase in the level of As (III) treatment, with the exception of the roots of Pant-12 seedlings where no consistent decrease in phosphate level on a dry weight basis could be observed (Figure 1). Moreover, during the 10-20 d period of growth $50 \mu \mathrm{M} \mathrm{As}_{2} \mathrm{O}_{3}$ led to a decline of about 32 to $60 \%$ in the Pi content in roots of Malviya-36 compared to the level in the controls. In shoots of both rice cultivars a decline in phosphate content of about 9 to $36 \%$ was found in $25 \mu \mathrm{M}$ in situ arsenite-treated seedlings and a decline of about 19 to $39 \%$ in $50 \mu \mathrm{M}$ arsenite-treated seedlings compared to the control values.

Effect of arsenite in situ on acid phosphatase activity: Figure 1 shows the effect of in situ arsenite treatment on acid phosphatase activity in growing rice seedlings. With increasing As (III) level in the growth medium a marked decrease in enzyme activity was observed in both roots as well as shoots. In roots, with $50 \mu \mathrm{M}$ As (III) treatment about 34 to $77 \%$ inhibition in enzyme activity was observed during 15-20 d of growth whereas in shoots under similar conditions about 30 to $50 \%$ inhibition in enzyme activity was observed.
Effect of arsenite in situ on alkaline phosphatase activity: In shoots of seedlings of both rice cultivars cultivated without arsenite in the medium, alkaline phosphatase activity was maximum at 20-d of growth but with increasing arsenite concentration in the growth medium a concomitant inhibition in enzyme activity was observed (Figure 1). At the moderately toxic level of 25 $\mu \mathrm{M} \mathrm{As} \mathrm{O}_{3}$ in the medium about 15 to $24 \%$ inhibition in alkaline phosphatase activity was observed in shoots of 20-d seedlings, whereas with the $50 \mu \mathrm{M} \mathrm{As}_{2} \mathrm{O}_{3}$ treatment about 28 to $36 \%$ inhibition was observed. In roots, on the other hand, no significant alteration in the activity of alkaline phosphatase could be observed in either rice cultivars due to the in situ arsenite treatment.

Effect of arsenite in situ on inorganic pyrophosphatase activity: Varietal differences as well as growth stage specific alterations in activity of inorganic pyrophosphatase were observed due to in situ As (III) toxicity (Figure 2). In roots of cv. Malviya-36 a marked decline in enzyme activity was observed with increasing levels of As throughout the 5-20 d growth period under study. However, although in shoots of this cultivar enzyme activity also declined with in situ As treatment during the 5-10 d period of growth, over the 15-20 d period elevation in pyrophosphatase activity was observed under arsenite toxicity. In roots of cv. Pant-12 during the 5-20 d growth period As (III)-treated (25 and 50 $\mu \mathrm{M})$ seedlings had higher enzyme activities compared to controls whereas in shoots activity declined under similar conditions.

Effect of arsenite in situ on mitochondrial and chloroplastic adenosine triphosphatase activity: As evident from Figure 2, in seedlings of both rice cultivars, mitochondrial ATPase activity consistently declined with increasing level of arsenite in the growth medium. In control seedlings maximum enzyme activity was observed in shoots at day 15 and in roots at 10-15 days. An in situ $25 \mu \mathrm{M} \mathrm{As}_{2} \mathrm{O}_{3}$ treatment led to about 16 to $32 \%$ inhibition of mitochondrial ATPase activity in roots and about 21 to $42 \%$ inhibition in activity in shoots, whereas seedlings growing in presence of $50 \mu \mathrm{M}$ As (III) in the medium showed about 28 to $50 \%$ inhibition in enzyme activity in roots and about 17 to $50 \%$ inhibition in shoots. A moderately toxic As treatment level of $25 \mu \mathrm{M}$ led to an 


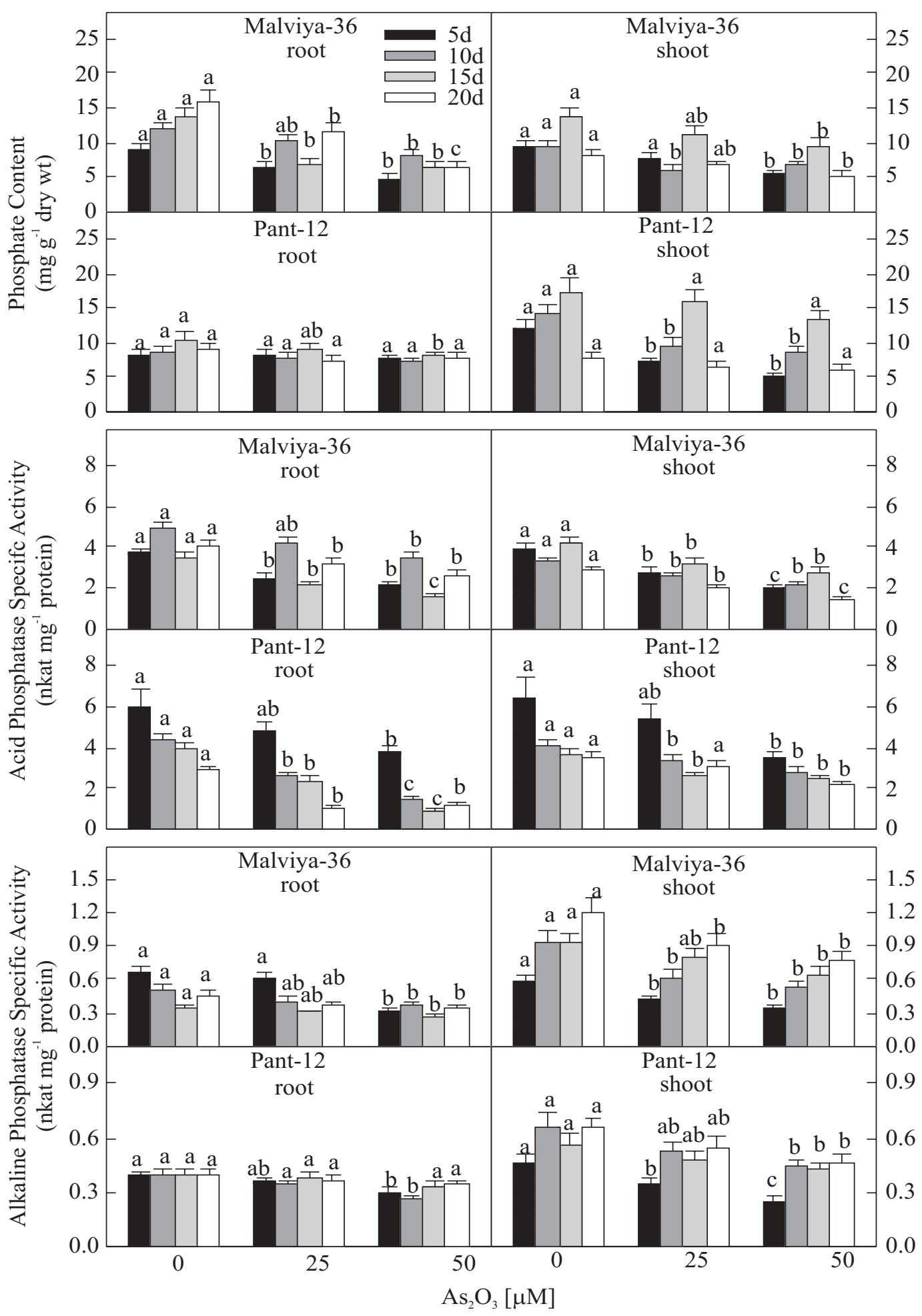

Figure 1. Phosphate content, acid and alkaline phosphatase specific activities in roots and shoots of seedlings of rice cvs. Malviya-36 and Pant-12 at different days ( 5 to $20 \mathrm{~d}$ ) of growth under increasing levels of $\mathrm{As}_{2} \mathrm{O}_{3}(0,25,50 \mu \mathrm{M})$ in the medium. Values are the mean \pm SD based on three independent determinations. Bars headed by different letters represent significantly different values at $P<0.05$. To determine phosphate content oven-dried samples were used whereas for enzyme activity measurements freshly harvested seedlings were employed. 


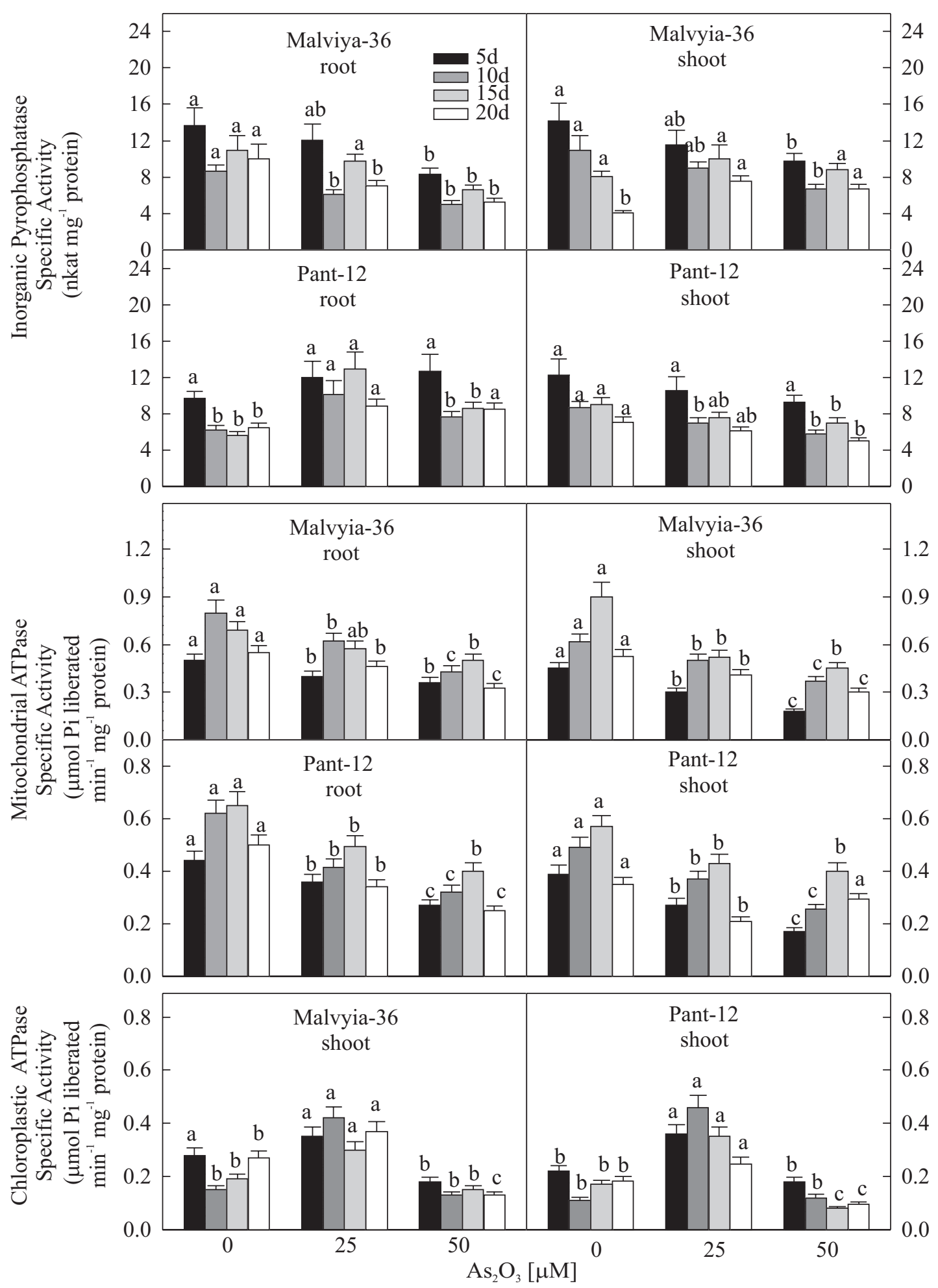

Figure 2. Inorganic pyrophosphatase and mitochondrial as well as chloroplastic adenosine triphosphatase specific activities in roots and shoots of seedlings of rice cvs. Malviya-36 and Pant-12 at different days (5 to $20 \mathrm{~d}$ ) of growth under increasing levels of $\mathrm{As}_{2} \mathrm{O}_{3}(0,25,50 \mu \mathrm{M})$ in the medium. Values are mean \pm SD based on three independent determinations. Bars headed by different letters represent significantly different values at $P<0.05$. Enzyme activities were determined using freshly harvested seedlings. 
increase in chloroplastic ATPase activity in the seedlings, however with the higher As treatment level of $50 \mu \mathrm{M}$ a decline in enzyme activity was noted (Figure 2). Under $25 \mu \mathrm{M}$ arsenite treatment, about 35 to $37 \%$ increase in enzyme activity was observed in 20-d-grown seedlings whereas under similar conditions $50 \mathrm{mM}$ arsenite treatment resulted in about 21 to $48 \%$ inhibition in enzyme activity compared to controls.

\section{DISCUSSION}

Results of the present study indicate an overall decline in the phosphate pool and inhibition in activities of the key phosphorolytic enzymes acid phosphatase, alkaline phosphatase and mitochondrial adenosine triphosphatase, as well as variable activity behaviour of inorganic pyrophosphatase and chloroplastic ATPase in rice seedlings growing in the presence of arsenite in the medium. Our earlier studies using these two rice cultivars indicated that $\mathrm{As}_{2} \mathrm{O}_{3}$ levels of $25 \mu \mathrm{M}$ and $50 \mu \mathrm{M}$ were respectively moderately and highly toxic to the rice plants and such As-treated plants showed reduced growth and inhibited activities of key nitrogen assimilatory, proteolytic and nucleolytic enzymes (Jha and Dubey, 2004; Mishra and Dubey, 2006).

Arsenate and arsenite are two phytoavailable forms of inorganic arsenic. Acquisition of these two arsenic species in plants takes place via distinct mechanisms. Arsenate is a phosphate analogue, remains relatively immobile in the soil and utilizes a phosphate transport mechanism for its uptake in plants, whereas arsenite, the more toxic form, is more mobile and is transported into roots via aquaglyceroporins (Meharg and Jardine, 2003; Tripathi et al., 2007 ). In our experiments a decline in the total phosphate pool was observed in rice seedlings with in situ arsenite treatment. Such a decline could be either due to a decrease in Pi concentration in the cytosol or due to modifications of vacuolar and/or cell wall pools of Pi. To tune the pace of growth and rate of physiological reactions in plant cells, availability of orthophosphate anion is a pre-requisite. It regulates the process of sugar metabolism (Giaquinta, 1980) and carbon partitioning (Khamis et al., 1990) besides serving as one of the primary substrates of photosynthesis (Plesnicar et al., 1994). The phosphorolytic enzymes regulate the Pi supply to various parts of the growing plants (Mittal and Dubey, 1992). The decline in phosphate content under As (III) toxicity as noted in our studies is correlated with decreased activity of phosphatases under such conditions, which may prove detrimental for proper growth of seedlings and establishment of rice plants in an As (III) polluted environment.

The enzyme acid phosphatase has been reported to have an intracellular as well as an extracellular localization (Duff et al., 1994). Both of these forms respond dramatically to cellular Pi status (Barret-Lannard et al., 1982; Duff et al., 1991). Alteration in the activity of acid phosphatase in plants has been observed under variety of stressful conditions including under toxicities due to various metals (Shah and Dubey, 1998; Sharma and Dubey, 2005). A number of metal ions are known to serve either as activators for acid phosphatase activity (Yupsanis et al., 1993) or inhibitors (Guo and Pesacreta, 1997; Tabaldi et al., 2007). It has been found that arsenate along with other phosphate analogues viz. molybdate, ascorbate, tartarate and vanadate serve as potent competitive inhibitors of plant acid phosphatase (UllrichEberius et al., 1989; Duff et al., 1991). Our results indicated a pronounced decrease in acid phosphatase activity in $\mathrm{As}_{2} \mathrm{O}_{3}$-treated rice seedlings. In spite of the fact that acid phosphatase is induced by low Pi status (Carpene and Wynne, 1986), the reduced Pi content due to As (III) observed in our studies was ineffective for induction of acid phosphatase activity. This might be due to the fact that arsenite is an inhibitor of acid phosphatase or that As (III) toxicity conditions lead to reduced synthesis of the enzyme protein. It is noteworthy that alkaline phosphatase is also inhibited by higher concentrations of the metals $\mathrm{Zn}^{2+}, \mathrm{Cd}^{2+}, \mathrm{Cu}^{2+}, \mathrm{Hg}^{2+}$, $\mathrm{Mo}^{6+}$ (Carpene and Wynne, 1986; Angosto and Matilla, 1990). One possible reason for metal-induced inhibition of alkaline phosphatase activity appears to be the capability of metal ions to replace $\mathrm{Zn}^{2+}$ from the active site of alkaline phosphatase resulting in changes in enzyme conformation and consequently inhibition of activity (Price and Morel, 1990). Nevertheless, the higher activities of acid and alkaline phosphatases seen under non-stressed conditions indicate that higher phosphorolytic activity is necessary to fulfill the needs of growing rice seedlings.

Environmental extremes such as anoxia, salt stress, 
osmotic stress and severe Pi-starvation lead to significant induction of tonoplast $\mathrm{H}^{+}$-pyrophosphatase (Palma et al., 2000; Fukuda et al., 2004). Under conditions of salt and osmotic stress increased $\mathrm{H}^{+}$-PPase gene expression resulted in enhanced pyrophosphatase activity (Fukuda et al., 2004). Earlier studies conducted with metals like $\mathrm{Cd}^{2+}, \mathrm{Co}^{2+}$ and $\mathrm{Cu}^{2+}$ showed an inhibitory effect of these metals on pyrophosphatase activity (Maeshima, 1991). However, in our studies varietal as well as organ-specific differences were observed for alteration in inorganic pyrophosphatase activity with increase in in situ As (III) treatment. Arsenite caused altered activity behaviour of inorganic pyrophosphatase which suggests that under As (III) toxicity there might be impairment of biosynthetic events in the seedlings due to inadequate utilization of pyrophosphate. There is no definite explanation for these observations although one possible reason appears to be the different genetic makeup of the two rice cultivars used. Physiological and biochemical studies have demonstrated that sequestration of potentially toxic compounds, possibly by vacuolar pyrophospatase, may lead to altered behaviour of these enzymes when subjected to environmental constraints (Vogeli-Lange and Wagner, 1989).

Our studies deal primarily with the soluble form of PPase because under our experimental conditions only the soluble form of PPase could be extracted and therefore the membrane-bound form was ignored.

In our experiments, although a moderately toxic level of $25 \mu \mathrm{M} \mathrm{As} \mathrm{O}_{3}$ caused an increase in chloroplastic ATPase activity, $50 \mu \mathrm{M} \mathrm{As}_{2} \mathrm{O}_{3}$ in situ was inhibitory to both mitochondrial and chloroplastic ATPase. Alteration in the activity of ATPase has been observed under a variety of environmental stresses (Sanchez-Aguayo et al., 1991, Astolfi et al., 2003, Debez et al., 2006). A decrease in ATPase activity and a direct inhibition of ATP hydrolysis was observed under $\mathrm{Cd}$ toxicity in oat roots (Astolfi et al., 2003) and under salinity in tomato roots (Sanchez-Aguayo et al., 1991). Similarly, $\mathrm{Hg}^{2+}, \mathrm{NaCl}$ and $\mathrm{KCl}$ have been reported to be inhibitory to $\mathrm{H}^{+}$-ATPase activity (Martinez-Ballesta et al., 2003). The inhibitory effect of As (III) on ATPase activity as observed in our studies might be a result of the strong affinity of arsenite for essential sulphydryl groups of the enzyme (Meharg and Hartley-Whitaker, 2002). Indeed, it has been suggested that the toxicity of arsenite in plant cells could be due to its binding to sulphydryl groups of proteins/ enzymes (Tripathi et al., 2007)

The results of the present study indicate that the presence of sublethal concentrations of As (III) in the growth medium of rice plants alters the phosphate pool within the plant and impairs phosphate mobilization by inhibiting the activities of key phosphohydrolases. Limited availability of phosphate and inhibition of the activities of phosphohydrolases would hamper energy metabolism and would ultimately contribute to an overall decline in the growth of rice plants in arsenite contaminated soils.

Acknowledgements: S Mishra is grateful to University Grants Commission, New Delhi for the award of a Senior Research Fellowship.

\section{REFERENCES}

Abedin MJ, Feldmann J, Meharg AA (2002) Uptake kinetics of arsenic species in rice plants. Plant Physiol. 128:1120-1128.

Angosto T, Matilla A (1990) Partial purification and some biochemical properties of non-specific alkaline phosphatase in germinating chick-pea (Cicer arietinum) seeds. Physiol. Plant. 80:136-142.

Astolfi S, Zuchi S, Chiani A, Passera C (2003) In vivo and in vitro effects of cadmium on $\mathrm{H}^{+}$ATPase activity of plasma membrane vesicles from oat (Avena sativa L.) roots. J. Plant Physiol. 160:387-393.

Atal N, Pardha Saradhi P, Mohanty P (1991) Inhibition of the chloroplast photochemical reactions by treatment of wheat seedlings with low concentration of cadmium: Analysis of electron transport activities and changes in fluorescence yield. Plant Cell Physiol. 32:943-951.

Barret-Lennard EG, Robson A D, Greenway H (1982) Effect of phosphorus deficiency and water deficit on phosphatase activities from wheat leaves. J. Expt. Bot. 33:682-693.

Beknazarow BO, Valikhanov MN (2007) Properties of cotton inorganic pyrophosphatase. Appl. Biochem. Microbiol. 43:153-158.

Bradford MM (1976) A rapid and sensitive method for the quantitation of microgram quantities of protein utilizing the principle of protein-dye binding. Anal. 
Biochem. 72:248-254.

Carpene E, Wynne D (1986) Properties of an alkaline phosphatase from the dinoflagellate Peridinium cinctum. Comp. Biochem. Physiol. 83B:163-167.

Cooperman BS (1982) The mechanism of action of yeast inorganic pyrophosphatase. Methods Enzymol. 87:526-548.

Debez A, Saadaoui D, Balasubramanian R, Ouerghi Z, Koyro H W, Huchzermeyer B, Abdelly C (2006) Leaf $\mathrm{H}^{+}$ATPase activity and photosynthetic capacity of Cakile maritima under increasing salinity. Environ. Exp. Bot. 57:285-295.

Duff SMG, Lefebvre DD, Plaxton W C (1991) Purification, characterization and subcellular localization of an acid phosphatase from Brassica nigra suspension cells: Comparison with phosphoenolpyruvate phosphatase. Arch. Biochem. Biophys. 286:226-232.

Duff SMG, Sarath G, Plaxton WC (1994) The role of acid phosphatase in plant phosphorus metabolism. Physiol. Plant. 90:791-800.

Ehsanpour AA, Amini F (2003) Effect of salt and drought stress on acid phosphatase activities in alfalfa (Medicago sativa L.) explants under in vitro culture. Afr. J. Biotechnol. 2:133-135.

Fiske CH, Subbarow Y (1925) The colorimetric determination of phosphorus. J. Biol. Chem. 66:375400.

Fukuda A, Chiba K, Maeda M, Nakamura A, Maeshima M, Tanaka Y (2004) Effect of salt and osmotic stresses on the expression of genes for the vacuolar $\mathrm{H}^{+}$pyrophosphatase $\mathrm{H}^{+}$-ATPase subunit $\mathrm{A}$, and $\mathrm{Na}^{+} / \mathrm{H}^{+}$ antiporter from barley. J. Expt. Bot. 55:585-594.

Giaquinta R T (1980) Translocation of sucrose and oligosaccharides. In: Preiss J (ed.), The Biochemistry of Plants, Vol. 3, pp.271-320, Academic Press, New York.

Green AV, Zheng Y, Cheng Z, He Y, Dhar RK, Garnier JM, Rose J, Seddique A, Hoque MA, Ahmed KM (2006) Impact of irrigating rice paddies with groundwater containing arsenic in Bangladesh. Sci. Total Environ. 367:769-777.

Guo J, Pesacreta JC (1997) Purification and characterization of an acid phosphatase from the bulb of Allium cepa L., var. sweet Spanish. J. Plant Physiol. 151:520-527.

Hoagland DR, Arnon D I (1938) The water culture method for growing plants without soil. Univ. Calif. Coll. Agric. Exp. Sta. Cir. Berkeley, CA, pp.347-353.

Jha AB, Dubey RS (2004) Arsenic exposure alters activity behaviour of key nitrogen assimilatory enzymes in growing rice plants. Plant Growth Regul. 43:259-268.

Khamis S, Chaillou S, Lamaze T (1990) $\mathrm{CO}_{2}$ assimilation and partitioning in maize plants deprived of orthophosphate. J. Exp. Bot. 41:1619-1625.

Maeshima M (1991) $\mathrm{H}^{+}$-translocating inorganic pyrophosphatase of plant vacuoles: inhibition by $\mathrm{Ca}^{2+}$, stabilization by $\mathrm{Mg}^{2+}$ and immunological comparison with other inorganic pyrophosphatases. Eur. J. Biochem. 196:11-17.

Martinez-Ballesta MC, Martinez V, Carvajal M (2003) Aquaporin functionality in relation to $\mathrm{H}^{+}$-ATPase activity in root cells of Capsicum annuum grown under salinity. Physiol. Plant. 117:413-420.

Meharg AA, Hartely-Whitaker J (2002) Arsenic uptake and metabolism in arsenic resistant and nonresistant plant species. New Phytol. 154:29-43.

Meharg AA, Jardine L (2003) Arsenite transport into paddy rice (Oryza sativa) roots. New Phytol. 157:3944.

Meharg AA (2004) Arsenic in rice - understanding a new disaster for South-East Asia. Trends Plant Sci. 9:415417.

Mishra S, Dubey RS (2006) Inhibition of ribonuclease and protease activities in arsenic-exposed rice seedlings: role of proline as enzyme protectant. J. Plant Physiol. 163:927-936.

Mittal R, Dubey RS (1992) Mitochondrial acid phosphatase and adenosine triphosphatase in germinating rice seeds following $\mathrm{NaCl}$ salinity stress. Indian J. Plant Physiol. 35:174-181.

Onken BM, Hossner L R (1995) Plant uptake and determination of arsenic species in soil solution under flooded conditions. J. Environ. Qual. 24:373-381.

Orhanović S, Pavela-Vrancic M (2000) Alkaline phosphatase activity in sea water: Influence of reaction conditions on the kinetic parameters of ALP. Croat. Chim. Acta 73:819-830.

Palma DA, Blumwald E, Plaxton WC (2000) Upregulation of vacuolar $\mathrm{H}^{+}$-translocating pyrophosphatase by phosphate starvation of Brassica napus (rapeseed) suspension cell cultures. FEBS Lett. 486:155-158.

Plesnicar M, Kastori R, Petrovic N, Pankovic D (1994) 
Photosynthesis and chlorophyll fluorescence in sunflower (Helianthus annus L.) leaves as affected by phosphorus nutrition. J. Exp. Bot. 45:919-924.

Price NM, Morel FMM (1990) Cadmium cobaltsubstitution for zinc in a marine diatom. Nature 344:658-660.

Requejo R, Tena M (2006) Maize response to acute arsenic toxicity as revealed by proteome analysis of plant shoots. Proteomics 6:5152-5162.

Saloman TG, Farineau N, Cantrel C, Oursel A, Tuquet C (1987) Isolation and characterisation of developing chloroplasts from light-grown barley leaves. Physiol. Plant. 69:113-122.

Sanchez-Aguayo I, Gonzalez-Utor AL, Medina A (1991) Cytochemical localization of ATPase activity in salttreated and salt-free grown Lycopersicon esculentum roots. Plant Physiol. 96:153-158.

Shah K, Dubey RS (1998) Cadmium suppresses phosphate level and inhibits the activity of phosphatases in growing rice seedlings. J. Agron. Crop Sci. 180:223-231.

Sharma P, Dubey RS (2005) Lead toxicity in plants. Braz. J. Plant Physiol. 17:35-52.

Szabo-Nagy A, Galiba G, Erdei L (1992) Induction of soluble phosphatases under ionic and non-ionic osmotic stresses in wheat. J. Plant Physiol. 140:629633.

Tabaldi LA, Ruppenthal R, Cargnelutti D, Morsch VM, Pereira LB, Schetinger MRC (2007) Effects of metal elements on acid phosphatase activity in cucumber (Cucumis sativus L.) seedlings. Environ. Exp. Bot. 59: 43-48.

Tominaga N (1978) A sulfite dependent ATPase of Thiobacillus thioxidans. Its partial purification and some properties. Plant Cell Physiol. 19:419-428.

Tominaga N, Takeshi M (1974) A sulfite dependent acid phosphatase of Thiobacillus thioxidans. J. Biochem. 76:419-428.

Tripathi RD, Srivastava S, Mishra S, Singh N, Tuli R, Gupta DK, Maathuis JM (2007) Arsenic hazards: strategies for tolerance and remediation by plants. Trends Biotechnol. 25:158-165.

Ullrich-Eberius C, Sanz I A, Novacky A J (1989) Evaluation of arsenate- and vandate-associated changes of electrical membrane potential and phosphate transport in Lemna gibba G1. J. Exp. Bot. 40:119-128.

Vincent JB, Crowder MW, Averill BA (1992) Hydrolysis of phosphate monoesters: a biological problem with multiple chemical solutions. Trends Biochem Sci. 17:105-110.

Vogeli-Lange R, Wagner GJ (1989) Subcellular localisation of cadmium and cadmium-binding peptides in tobacco leaves. Plant Physiol. 92:1086-1093.

Wedding RT, Black M K, Pap D (1976) Malate dehydrogenase and NAD malic enzyme in the oxidation of malate by sweet potato mitochondria. Plant Physiol. 58:740-743.

Williams PN, Raab A, Feldmann J, Meharg, AA (2007) Market basket survey shows elevated levels of arsenic in south central US grain processed rice compared to California: consequences for human dietary exposure. Environ. Sci. Technol. 41:2178-2183.

World Bank, Water and Sanitation Programme (WSP) (2005) Arsenic contamination of ground water in South and East Asian countries: towards a more effective operational response, Washington D.C., USA, World Bank, 2Vols., Report No. 31303.

Yupsanis T, Eleftheriou P, Pantazaki A, Georgatsos JG (1993) Multiplicity of metal independent protein phosphatases of germinated alfalfa seeds. J. Plant Physiol. 141:257-262. 